\title{
The End of Pedagogy?
}

\section{A Plea for Concrete Utopian Acting and Thinking}

\section{Siebren Miedema}

University of Groningen

\section{Introduction}

It seems that something is gnawing at the roots of existing certitudes. Unemployment, ecological destruction, and never-ending food shortages suffered by large parts of the world population make us doubt the relevance and practical import of political and world views.

Should one expect any benefit from philosophical discussions? Foucault has broken with the dialectical and progressive idea of history and with the idea of an autonomous subject. Postmodern philosophers like Lyotard have rejected as transcendental illusions the assumptions of the project of modernity, of the Enlightenment. And the speechmaking philosopher Rorty seems to have developed a love-hate relation with this project. In his opinion the pretenses of modernity are achievable only in regard to social democracy.

What might pedagogy contribute to the general sense of malaise? Some have argued that educational discourse of the postmodern period has led to the phase of postpedagogy. In contrast to the philosophical approaches mentioned above, the project of pedagogy as Enlightenment project is still being debated. In the most radical version of the critique this project has been characterized as phantasmagorical. The concept of emancipation is over and done with, it was a fata morganasacred water in an oasis not to be found anywhere, a quixotry of modernity (Niess, 1985, p. 13).

In the face of this postmodern situation, should not every educator resign? I don't think so, but it must be made clear what our situation is when viewed from a more positive perspective. First, the postmodern constituents of the pessimistic Zeitgeist need to be exposed. Next, I examine how more productive views of contemporary pedagogy can be formulated. Finally, I examine the question of whether there is any room left for the continuation of modernity as pedagogical project on the basis of a concrete pedagogical Utopia. What are the consequences of such a view for the concept of personal responsibility at the end of the 20th century? 


\section{The End of the Modernity Project?}

One of the greatest threats to the survival of pedagogy as a theoretically founded practice has come from philosophy. Foucault, Lyotard, and Rorty are laying siege to the Enlightenment bastion currently guarded by Habermas. In Habermas' view history is a process that carries the necessary conditions for humanization. In his Theory of Communicative Action (Habermas, 1984/87) attempts to lay the foundations for theoretical and practical social-scientific research that will maximize problem solving in a democratic way. In politics he still adheres to the ideal of progressive social democracy: freedom of opinion, participation in decision making. In science he continues to maintain the primacy of the validity claim of truth.

Habermas has been criticized by postmodern and neopragmatist thinkers on precisely these two points. Foucault (1985) argues that Habermas' idea of growing rationality and historical progress is theoretically unacceptable. Foucault proposes the existence of a neverending struggle between rational and irrational power. Words and signs do not in the first place refer to factual reality and do not serve to represent this reality as adequately as possible. They primarily refer to a network of power positions. This network de facto constitutes the reality of spoken and written words (the discourse as oration) and also results from it. According to Foucault, discourses do not form a unity, converge, or have a beginning or an end. In contrast with the Enlightenment ideas there exists no unifying permanent-neutral discourse that can legitimize the diversity of discourses. Knowledge and power are related to one another circularly. "There is no power relation without the fact that any field of knowing comes into being at the same time: there is no knowledge that does not presuppose and constitute power relations" (de Mul, 1987, p. 467).

The modern assumption of the autonomous subject is completely undermined by postmodern thought. The human subject always needs to be interpreted as the effect of discourses. We can speak in a twofold way about the constructed character of the subject. The subject is not ahistorical, transcendentally given, but a product of the human sciences and the modern epistemological organization. The subject, according to Foucault, is also empirically constructed by means of pedagogical practices characterized by power that are connected with human scientific knowledge about the subject. There is an identity between subjectivity and control or power positions. Subjects are constituted entirely by the working of power. Foucault wants to develop new forms of subjectivity by refusing the type of individuality imposed on us over the centuries, and he refers here to Kant's famous text What is Enlightenment? The pressing question is whether there are still possibilities for such a development beyond disciplinary and pastoral power. 
Habermas criticizes Foucault for eliminating the dialectical character of the modernity project. For example, Foucault does not show in his research on the reform of criminal law what the improvements are from the perspective of the persons involved. As Habermas points out, Foucault forgets to look at the dialectical reverse side of the things. $\mathrm{He}$ does not take into account that despite negative effects on one level, at the same time improvements are possible on another, and so tensions between the two levels exist (Korthals \& Kunneman, 1983, p. 310).

Lyotard (1987) is heading in the same direction as Foucault, but he is a more radical proponent of the postmodern stance. According to Habermas (1985a), Foucault was once again enchanted with the philosophical discourse of modernity. Foucault's claim that he says certain things "only because it is my opinion that they can change reality" (1985, p. 90) betrays his modernist principle.

Lyotard (1987) also deals in no uncertain way with the political side of the enlightenment project. Within his metaphysics of the absolute lack of a reverse side to truth he argues that there is no dialectical other side to social truth. He rejects the legitimation discourse of modernity, the metanarrative of emancipation, the faith in the rational subject and rational humanity, and the dialectic of spirit. In postindustrial, postmodern societies knowledge can only consist in disbelief in the metanarratives of modernity. According to Lyotard, what remains is the heterogeneity of language games. There are "narrative, but also denotative, prescriptive, descriptive and other speech elements each with their own pragmatic valencies sui generis. Everyone is living at the intersections of many of these valencies" (p. 26). Autonomous selfdetermination of the subject is an impossibility, says Lyotard. Humans do not start by speaking, but by listening to the different narratives. The result of this process is heteronomy instead of autonomy.

Rorty (1979) takes an intermediate position between modernists and postmodernists. In Philosophy and the Mirror of Nature he makes it clear, via an analysis of the work of philosophers like Descartes, Locke, and Kant, that the stance of philosophy as epistemology, as founding discipline, must be rejected as a pretense that cannot be justified. Especially the associated ideas of knowledge as representation or as pure mirroring of reality are dismissed. The "certainty-tag" attached to knowledge cannot be based on a causal-mechanical model, but is based on social practices, argumentation, and conversation (pp. 96-97; 156157).

Rorty (1979) seems to formulate an epistemological behaviourism that ends in a language game philosophy, inspired by Dewey $(1925,1938)$ and Wittgenstein, in which there is no room left for a permanent neutral matrix for the assessment of research and historical processes. Rorty (1979) substitutes philosophy as epistemology for philosophy as 
hermeneutics. In the practice of conversations the hope is for agreement as long as the conversation lasts and one is freed from the epistemological presupposition "that there is a special set of terms in which all contributions to the conversation should be put" (p. 318).

Rorty (1979) admits that there is a task reserved for epistemology, but only as vehicle for reconstruction, as metadiscourse of the normal discourse, that is, the discourse in which the participants have reached consensus. Striving for objective knowledge does not yield a permanent neutral matrix for the legitimation of the products of knowledge, but such striving may offer the nonprivileged contribution of the philosopher to "the conversation of mankind" (p. 389).

Philosophy as hermeneutics wants to understand social practices, but with the goal in mind that the standard question that arises in every hermeneutical-philosophical and hermeneutical-pedagogical approach is: How is critique on these practices possible? This question can be answered on the basis of Habermas' theory of communicative action, but not from a Rortyan perspective. Habermas maintains a focus on the relation between philosophy as critical theory, research in the empirical social sciences, and social praxis. Habermas and Rorty agree on one point: the ideal of social democracy. They meet each other halfway in the framework of the modernity project. Both criticize Foucault's linking of knowledge and power and his skepticism in regard to the Western ideal of democracy. They both argue that it is possible to distinguish between societies based on violence and those that find their basis in argumentation, discourse, and conversation. In Rorty's opinion such a philosophical view of politics is possible because "there is no inferential connection between the disappearance of the transcendental subject-of 'man' as something having a nature that society can repress or understand-and the disappearance of human solidarity. Bourgeois liberalism seems to me the best example of this solidarity we have achieved, and Deweyan pragmatism the best articulation of it" (Rorty, 1982, p. 207).

But Rorty is of the opinion, in contrast to Habermas, that philosophy and the social sciences do not have a privileged role to play over and above literature, music, and theater when trying to maximize concrete politics and when contributing democratically to political organizations.

It seems that the criticism of poststructuralists, postmodernists, and neopragmatists does not have sufficient argumentative power to enforce the following conclusion as necessary and inevitable: the modernity project has come to an end. A different interpretation of the postmodern situation is possible, and in my opinion also more adequate. Foucault and Rorty broach subjects that have to do with crises that crop up when completing the project of modernity, and they are 
quite sensitive on that point. They are completely right that the status of ontology, metaphysics, epistemology, and democracy is at issue here. Both Foucault and Rorty react to the sometimes overstrained expectations that could not be met in this project.

Lyotard is a different story. It seems that only he pays tribute to a real antimodernity stance. But is not his criticism and relativism derived from and based on the constituents of precisely the modernity project he is criticizing?

\section{Modernity versus Postmodernity and Pedagogy}

What kind of reactions in pedagogy have been moved forward in relation to the postmodern situation? Baacke (1985) is a good example of the tired disillusionment that the political turn has created for some educators and that has led to a postmodern withdrawal. The concept of emancipation is dismissed, and the assumption of continuous progress is reduced to something sought by prestige-seeking scientists. Baacke adheres to the postmodern new wave in pedagogy, which only has room for an ironical pedagogy. "In such a pedagogy there is room for irritation and that is more than merely speaking on different or conflicting ideas. Liberation from the pedagogical relation may soon be possible" (1985, p. 212). It appears the end of education and pedagogy is unavoidable.

An interesting reaction to this concept of ironical pedagogy came from the German pedagogue Mollenhauer. He wants to continue the project of modernity and that is a normative choice for "the systematical intention of ushering the younger generation along gradual stages into the given world, where in every stage humaneness, sub specie aeternitatis, should not be forgotten" (1986, pp. 174-175).

Pedagogy has always been a concrete, historically determined activity, and Mollenhauer illustrates this with historical examples. Pedagogy should aim at general education (Bildung) rather than at a schooling form of education (Erziehung) that leads to a narrow, goal-oriented, methodical, and systematic interaction with children and youngsters. Then the focus of education could change toward the potentially Bildung qualities of the form of life that adults present and model to children. An important question is whether presentation of one's own mature life and chosen way of living could be such that "it could be accounted for in relation to and in dialogue with the issues at stake in my culture from the perspective of me and the future of my children, if I have any, or if I am responsible for any children" (Mollenhauer, 1986, p. 10).

Mollenhauer stays within the legitimation discourse of modernity. He is looking for a pedagogical concept related to the educational reality in 
which Bildung gets a chance. This is the only way the modern pedagogical project and the democratic ideal can survive.

\section{Postmodern View, Pedagogy, and the Future}

What needs to be done in order to overcome the postmodern predicament? From a pedagogical point of view we should, in line with Rorty, avoid every foundationalism related to ontology and epistemology and plead for a renewed attention for value orientation and ethics. Dealing with such a perspective of openness in a value-oriented sense, we can try to rediscover the pedagogical meaning of the concepts future and Utopia. Utopia has always played a crucial role in pedagogical thought. Utopia is the form of the not-yet the forward-pushed eye of mankind on the way to greater clarity and greater maturity. Utopia shows us something about people's expectations of the future. Educators are not merely concerned with their own future, but also, and perhaps especially, with the future of their children. An important question is whether our present postmodern view of the future can still accommodate pedagogical relations and actions that will serve the good of our children.

In Ministering Insight Beekman (1973) deals with this issue in a penetrating manner. He pays attention to the relation between Bildung (maturity, future) and critique. For Beekman, maturity means responsibility and independence. The mature adult and the not-yet mature child are directed to the future, toward the later maturity of the child. The adult believes in the potential autonomy and responsibility of the child. Without this potential autonomy, responsibility, and solidarity with the child, pedagogy and pedagogical reflection are impossible.

Pedagogical theory connects to practice, according to Beekman, by means of an immanent and prospective form of critique. Through immanent critique, normative conflicts in existing situations are detected and clarified, and afterward ways are sought of solving these problems. By means of the prospective critique "the pedagogical theorist looks for new possibilities of form, for new structures that can take away the existing blockages to freedom, hindrances to opportunities for independence" (Beekman, 1973, p. 62). Present obstacles brought to light by immanent critique ought to be prevented in the future on the basis of prospective critique. In order to realize this program one needs to keep the future in sight: here-and-now knowledge should be combined with Utopian ideas. In Beekman's conception, Utopia is "imagination, a plan for an ideal society with an ideal Bildung ... In pedagogical theory Utopia will be 'the kingdom of freedom' in which the independent development of persons will be something that goes without saying. It contains the old ideals of freedom, equality, and fraternity. Without these ideals every criterion is relative" (pp. 62-63). 
Crucial for continuing the modern pedagogical project is the belief of mature adults in the future. The plan for a normatively ideal future is called Utopia. In postmodern philosophical and pedagogical views this belief in a regulative, normative ideal has been lost to a certain degree; probably because of this loss philosophers and pedagogues share the conviction that the concept of Utopia is an aspect of the metanarrative par excellence. Habermas' communicative theory of society understands this ideal to be a basic assumption that, through language and through communication, will create the possibility for political awareness. Autonomy and solidarity are realizable in society.

Plans for the future can be varied, and the choices we make are significant. In a useful Utopia today, past and future must have the opportunity of relating to each other. A Utopia ought to have criticalconstructive power; this means that besides evaluating the obstacles to Utopia, constructive indications should be provided as to how the not-yet of today could be given active shape. This means that a Utopia to become relevant for pedagogy must be concrete, not abstract.

\section{Pedagogy and Utopia}

"When introducing children into an adult world," says Dasberg, we "not only have to translate that world pedagogically; we also have to believe in this world" (1983, p. 125). The same is true for the pedagogical theorist as the one who is reconstructing practice in service of that practice.

This belief that Dasberg is speaking of has been pointed to as hope or concrete Utopia. It is a regulative ideal or principle that screens reality in a critical way. An attempt is made on the basis of available knowledge to realize this ideal in practice. At the same time, one must be aware that a Utopia cannot be realized in any direct empirical way. The Utopia can be adjusted on the basis of concrete pedagogical and practical-political experiences.

Sauer (1964) has distinguished between a set of four Utopian-pedagogical conceptions: the political, the rational-progressive, the mythical, and the revolutionary. Besides these distinctions and partly running through them is the important difference between abstract and concrete Utopias (Bloch, 1963). In a concrete Utopia, the present and the future come together; an analysis of both the situation and the prospective aspect are necessary. Characteristic of the abstract Utopia is the absence of a critical-realistic relation with the situation of today.

In political Utopias education is used as an instrument in realizing political ideals. In these types we find no free persons with individual capacities, but only persons seen from the perspective of the state. They appear here as half-persons, as reduced persons. 
In rational-progressive Utopias there is an unlimited reliance on pedagogy, and whether culture can flourish is dependent on the appropriate use of education. The 18th-century Utopias of the pedagogical modernity movement are of this kind. The assumption of rational-progressive Utopias is that the good life can be brought about by rational thinking and acting. In this way education can bring about changes in society. Utopians such as Rousseau, Pestalozzi, and Salzmann often saw the farming classes as the ideal of the new rational and healthy human being. Frequently there was a great reliance on technical inventions. These Utopian images originated from thought and were largely philosophical-speculative in character.

In mythical Utopias an image is projected on the past and used as a model for action. These are retrospective Utopias without any relation with the here-and-now reality. Examples of this type are the mythical Utopias in the German youth movement during the Weimar Republic. They were not connected in any concrete way to real life and could be easily appropriated by extreme political forces such as the Nazis.

In revolutionary Utopias there is only room for a revolutionary pedagogy after the revolution has taken place. It is for this reason that after a rather enthusiastic reception during the first decades of this century the ideas of the leftist reform minded pedagogues Kerschensteiner and Dewey were rejected by Krupskaja, Lunatscharsky, and Blonsky, because these ideas could not bring about the revolution. The ultimate example of a revolutionary pedagogy is the Utopian thought of Makarenko. The condition of his pedagogy is the perspective of the revolution as process. This perspective offers the opportunity for every individual to become free rather than oppressed. The revolutionary collective is the vehicle of the revolution, and with it tension arises between individuality and sociality as is reflected in Makarenko's pedagogy.

Against the failings of the political, rational-progressive, mythical, and revolutionary Utopias, a pedagogical Utopian perspective needs to be created that can still be relevant to the present situation of the child living in a postmodern world. This postmodern reality of the child needs to be related in a lifelike way to life in society with its culture, its social, political, economical contents and problems, and with its philosophies of life. Keeping an eye on the future, pedagogues should take an immanent critical stance in relation to today so that the individual can be related in a prospective way both to today and to the future on the basis of the regulative principles of autonomy and solidarity. Step by step the pedagogue should reveal the tasks and problems that need to be solved and to which the child can contribute when he or she is able to take full responsibility. The pedagogue must anticipate in her or his way of thinking and acting and by means of the pedagogical institu- 
tions at her or his disposal the tasks and possibilities of the future. Only when pedagogy centers itself on today, past, and future can we answer the question: what in the past has potential for Bildung for today and the future, based on the criteria of relative autonomy and solidarity (with other persons and nature)? "Only that content from the past can have the power for Bildung which could be experienced by the child or youngster as his or her past-and this naturally in a more than only biographical sense; the past has potential for Bildung only when the young man or woman has an entrance to today and is not robbed of the courage for his or her future" (Klafki, 1958, p. 462).

\section{Epilogue}

At the end of the 20th century educators and pedagogues need not step down because the basic assumptions of the modernity project are in dispute. Of course, it is possible to criticize a concrete-Utopian, normative program. This has happened regularly throughout the history of philosophy. Such criticism may result in appropriate adjustments to the keynotes of the modernity Utopia (cf. Habermas, 1985b). The criticism of the poststructuralists, the postmodernists, and the neopragmatists, being a louse in the fleece of modernism, should be taken seriously.

Of course, it is impossible to pretend that an entire world, society, and whole people can be created by means of educational processes. Critical-hermeneutical and phenomenological pedagogical theory, philosophy, politics, and practice need to make a choice for relative autonomy and solidarity in the broad sense used before. This duo offers, on the one hand, the possibility for critical negativism: to show what reality is not-yet. On the other hand, this trio is the regulative criterion, the ideal for modeling the future: critical positivity.

The Utopian aspect in pedagogy can save educators from a canonization of the status quo and from irrelevant research practices. The unknown future makes a normative pedagogical and political appeal to educators to link their own actions related to Bildung and research to the future. Educators who do not want to link today with the future are shirking their responsibility. How can parents ever expect responsibility from their children if they do not take responsibility for their children?

\section{References}

Baacke, D. (1985). Bewegungen beweglich machen. Oder Plüdoyer für mehr Ironie. In D. Baacke et al., Am Ende Post-Modern? Next wave in der Pädagogik (pp. 190-213). Weinheim/München: Juventa.

Beekman, A.J. (1973). Dienstbaar inzicht [Ministering insight ]. Groningen: Tjeenk Willink.

Bloch, E. (1963). Ueber die Bedeutung der Utopie IOn the meaning of Utopia], In E.

Bloch, Tübinger Einleitung in die Philosophie I (pp. 124-132). Frankfurt: Suhrkamp.

Dasberg, L. (1983). Pedagogy in the year 2000. Phenomenology + Pedagogy, 1, 117-126. 
de Mul, J. (1987). De maakbaarheid van het subject. Foucault en de pedagogiek II [The makeable subject. Foucault and pedagogy l. Comenius, 7, 453-481.

Dewey, J. (1925). Experience and nature. New York: Dover.

Dewey, J. (1938). Logic: The theory of inquiry. New York: Irvington.

Foucault, M. (1985). Ervaring en waarheid [Experience and truth].

Meppel/Amsterdam: Boom.

Habermas, J. (1984/87). Theory of communicative action (vols. I \& II). Frankfurt: Suhrkamp.

Habermas, J. (1985a). Mit dem Pfeil ins Herz der Gegenwart. Zu Foucault's Vorlesung über Kants was ist Aufklärung. In J. Habermas, Die neue Unübersichtlichkeit (pp. 126-131). Frankfurt: Suhrkamp.

Habermas, J. (1985b). Die Krise des Wohlfahrtstaates und die Erschöpfung utopischer Energien. In J. Habermas, Die neue Unübersichtlichkeit (pp. 141-163). Frankfurt: Suhrkamp.

Klafki, W. (1958). Die Erziehung im Spannungsfeld von Vergangenheit, Gegenwart und Zukunft. Die Sammlung, 13, 448-462.

Korthals, M. \&, Kunneman, H. (1983). De theorie van het communicatieve handelen. Een vraaggesprek met Habermas [The theory of communicative action. An interview with Habermas]. Kennis en Methode, 7, 295-312.

Lyotard, J.-F. (1987). Het postmoderne weten [The postmodern condition]. Kampen: Kok.

Mollenhauer, K. (1986). Umwege. Ueber Bildung, Kunst und Interaktion. Weinheim/München: Juventa.

Niess, M. (1985). Das postmoderne Begehren nach Unvernunft. Oder: Das Vergnügen, einen Jaguar zu fahren. In D. Baacke et al., Am Ende Post-modern? Next wave in der Pädagogik (pp. 12-22). Weinheim/München: Juventa.

Rorty, R. (1979). Philosophy and the mirror of nature. Princeton, NJ: Princeton University Press.

Rorty, R. (1982). Consequences of pragmatism. Brighton: Harvester Press.

Sauer, K. (1964). Der utopische Zug in der Pädagogik. Weinheim: Beltz. 